\title{
Influence of aquaculture effluents on the growth of Salvinia molesta
}

Influência do efluente de aqüicultura sobre o crescimento de Salvinia molesta

Raquel Eduarda Trevisan Pistori ${ }^{1}$, Gustavo Gonzaga Henry-Silva ${ }^{2}$,

José Francisco Vicente Biudes ${ }^{1}$ and Antonio Fernando Monteiro Camargo ${ }^{1}$

${ }^{1}$ Departamento de Ecologia, Centro de Aquicultura - CAUNESP, Instituto de Biociências de Rio Claro, Universidade Estadual Paulista - UNESP, Av. 24 A, 1515, CEP 13506-900, Rio Claro, SP, Brazil

e-mail: raqueletp@yahoo.com.br, jfvbiudes@gmail.com, afmc@rc.unesp.br

${ }^{2}$ Departamento de Ciências Animais, Universidade Federal Rural do Semi-Árido - UFERSA,

BR110, Km 47, Presidente Costa e Silva, CEP 59625-900, Mossoro, RN, Brazil

e-mail: gustavo@ufersa.edu.br

\begin{abstract}
Objective: Aquaculture generates social and economic benefits, but also causes impacts on the environment. One of the major impacts is the release of untreated effluents into rivers, reservoirs, and lakes, which can affect aquatic populations and communities. In this study, we tested the hypothesis that effluent from aquaculture favors the growth of the floating aquatic macrophyte Salvinia molesta; Methods: The study was carried out in a non-impacted reservoir (NIR) and in another reservoir (IR) that is impacted by discharges of aquaculture effluents, and lasted for nine months. In each of the reservoirs, we installed four experimental units containing 10 ramets of $S$. molesta. Monthly, we measured limnological variables of the water and the biomass of $S$. molesta in both reservoirs; Results: The temperature, turbidity, electrical conductivity, alkalinity, chlorophyll- $a$, total Kjeldahl nitrogen, and total phosphorus were higher in the IR in all the collection months. At the end of the experiment, the concentrations of total nitrogen and phosphorus in the biomass of $S$. molesta from the IR were higher than those in plants from the NIR. The estimated support capacity (K) for $S$. molesta in the NIR was $3.0 \pm 0.7 \mathrm{~g}$ DM. $\mathrm{m}^{-2}$ and in the IR was $37.4 \pm 2.4 \mathrm{~g} \mathrm{DM} . \mathrm{m}^{-2}$; Conclusions: It was concluded that the discharge of aquaculture effluent modifies the limnological characteristics of the water of the receiving reservoir, and that the growth of Salvinia molesta is favored by the aquaculture effluent, because of the increases in the concentrations of nitrogen and phosphorus in the water.
\end{abstract}

Keywords: floating aquatic macrophyte, nutrients, support capacity, eutrophication, chemical composition.

Resumo: Objetivo: A aqüicultura gera benefícios sociais e econômicos, mas também causa impactos ao ambiente. Um dos principais impactos é o lançamento de efluentes sem tratamento em ambientes como rios, reservatórios e lagos, o que pode afetar populações e comunidades aquáticas. Neste trabalho foi testada a hipótese de que o efluente de aqüicultura favorece o crescimento da macrófita aquática flutuante Salvinia molesta; Métodos: $\mathrm{O}$ estudo foi realizado em uma represa não impactada $(\mathrm{RNI})$ e outra represa impactada (RI) por lançamentos de efluentes de aqüicultura e teve duração de nove meses. Em cada uma das represas foram fixadas quatro unidades experimentais contendo 10 rametes de $S$. molesta. Mensalmente, foram determinadas variáveis limnológicas da água e a biomassa de $S$. molesta nas duas represas; Resultados: Os valores de temperatura, turbidez, condutividade elétrica, alcalinidade, clorofila- $a$, nitrogênio Kjeldahl total e fósforo total foram superiores na RI em todos os meses do estudo. As concentraçóes de nitrogênio e fósforo total na biomassa de $S$. molesta da RI foram maiores do que as da RNI, ao final do experimento. Os valores de capacidade suporte (K) para $S$. molesta na RNI foram de 3,0 \pm 0,7 g MS. $\mathrm{m}^{-2}$ e na RI foi de 37,4 $\pm 2,4 \mathrm{~g} \mathrm{MS} . \mathrm{m}^{-2}$; Conclusóes: Concluiu-se que o lançamento de efluente de aqüicultura modifica as características limnológicas da água da represa receptora e que o crescimento de Salvinia molesta é favorecido pelo efluente de aqüicultura, provavelmente, devido ao aumento das concentraçóes de nitrogênio e fósforo na água.

Palavras-chave: macrófita aquática flutuante, nutrientes, capacidade suporte, eutrofização, composição química. 


\section{Introduction}

Aquaculture production generates social and economic benefits; however, like other productive activities, it causes changes in the environment. One of the major impacts caused by aquaculture is the production of wastewater that is rich in nutrients, especially phosphorus and nitrogen (Paéz-Osuna, 2001). The effluents contain feces, excreta, unconsumed feed, and plankton, which can alter the limnological characteristics of the receiving waterbodies and accelerate the eutrophication process. This artificial eutrophication, in turn, tends to reduce water quality and limit its use by humans, in addition to decreasing the biodiversity and richness of animal and plant species in the environment (Tundisi, JG. and Tundisi, TM., 2008).

The deleterious impacts of aquaculture, especially marine aquaculture, are widely documented in the literature (Read and Fernandes, 2003; Buschmann et al., 2009) and the impact on aquatic communities and populations has been studied by some authors. For example, Findlay et al. (2009) found an annual increase of $400 \%$ in the phytoplankton biomass and blooms of chrysophytes and dinoflagellates in areas near trout farms in lakes in Canada. The structure of the benthic macrofauna was altered in areas impacted by effluents from farming of marine shrimp (Canary et al., 2009). In Brazil the impact of aquaculture on aquatic communities and populations has been little studied. Henry-Silva and Camargo (2006) observed an increase in the biomass of species of floating aquatic macrophytes subjected to effluents of Nile tilapia (Oreochromis niloticus). A study on competition among floating aquatic macrophytes cultured in effluents from freshwater-shrimp breeding tanks (Macrobrachium amazonicum) found that Pistia stratiotes showed a competitive disadvantage in relation to Eichhornia crassipes (Henry-Silva and Camargo, 2005).

Aquatic macrophytes are an important community in aquatic environments where they are abundant, because they provide food for fish and invertebrates, are involved in nutrient cycling, and act in primary production (Duarte, 1995). Among the factors limiting the growth of these plants are the nutrient concentrations in the water, light, temperature, variations of water level, and current velocity (Biudes and Camargo, 2008). In this study, we tested the hypothesis that the effluent from aquaculture favors the growth of the floating aquatic macrophyte Salvinia molesta. This species was chosen because macrophytes of the genus Salvinia proliferate undesirably in many locations that are altered by human activities, which negatively affects multiple uses of the aquatic ecosystem with respect to electric-power generation, shipping, water supply, recreational uses, and fishing (Moozhiyil and Pallauf, 1986). In Brazil, S. molesta is widely distributed, occurring in natural aquatic ecosystems as well as in aquatic systems impacted by human activities (Bini et al., 1999; Henry-Silva and Camargo, 2000).

\section{Material and Methods}

The study was carried out in two reservoirs, one non-impacted (non-impacted reservoir, NIR) and the other impacted (impacted reservoir, IR) by discharges from fish and frog farms, located in the UNESP Aquaculture Center (CAUNESP), in the city of Jaboticabal, São Paulo, Brazil (21 $18^{\prime}$ S and $48^{\circ} 18^{\prime}$ W), from July/2003 through March/2004 (231 days). At the beginning of the study, we established four experimental units ( $1 \mathrm{~m}^{2}$ quadrats) in both reservoirs, each containing 10 ramets of $S$. molesta of similar size and appearance (approximately $15 \mathrm{~g}$ fresh mass per quadrat), near the shore of each reservoir. The experimental units were constructed with PVC pipe, and the bottom was covered by a plastic screen with $3 \times 4 \mathrm{~mm}$ openings, to prevent the plants from dispersing. The ramets were collected in a reservoir used for semi-intensive fish farming.

\subsection{Physical and chemical characteristics of the reservoir water}

At approximately 30-day intervals (monthly), we measured physical and chemical variables of the surface water in the two reservoirs, between 9:00 AM and 10:00 AM. Temperature, $\mathrm{pH}$, electrical conductivity, turbidity, and dissolved oxygen were measured with a Horiba model U-10 Water Quality Checker. Water transparency was determined with a Secchi disk. The concentrations of total Kjeldahl nitrogen (TKN) were determined as described by Mackereth et al. (1978). The total phosphorus (TP) contents were measured according to Golterman et al. (1978). The chlorophyll-a concentrations were determined according to the methodology described by Nusch (1980).

\subsection{Growth of S. molesta}

On the same day that the physical and chemical properties of the water were measured, all individuals of $S$. molesta in each experimental unit were collected and their fresh weight was determined with a semi- 
analytical balance. Before the fresh weight was measured, excess water was removed by allowing the plants to drain for five minutes (Agami and Reddy, 1990), and subsequently the ramets were returned to their respective experimental units. The dry mass of $S$. molesta was estimated by a simple linear regression (Zar, 1999) between the fresh and dry mass of the macrophyte samples of the same population used in the experimental units.

The logistic equation was adjusted to the values of dry mass to estimate the carrying capacity $(\mathrm{K})$ of each treatment. According to Krebs (1994), to represent the growth of a population in a logistic curve, it is necessary to have a stable initial distribution of individuals, units of measure appropriate for the population, the relationship between population density and growth rate should be linear, and the growth rate density-dependent. In this study, these factors were observed. We adjusted a logistic growth model for $S$. molesta in each reservoir through the parameterization of the following Equation 1:

$\mathrm{N}_{\mathrm{t}}=\frac{\mathrm{K}}{1+\mathrm{e}^{\mathrm{a}-\mathrm{r}_{\mathrm{m}}^{\mathrm{t}}}}$,

where $\mathrm{N}_{\mathrm{t}}=$ biomass $\left(\mathrm{gDM} \cdot \mathrm{m}^{-2}\right) ; \mathrm{t}=$ time (days); $\mathrm{K}=$ support capacity (maximum value of $\mathrm{N}$ ); $\mathrm{e}=2.71828$ (base of the natural logarithm); $\mathrm{a}=$ integration constant that defines the position relative to the curve at the origin; $r_{m}=$ intrinsic growth coefficient.

The intrinsic growth coefficients $\left(r_{m}\right)$ and the support capacities $(\mathrm{K})$ were estimated by adjusting the temporal variations of biomass to the sigmoid model (Krebs, 1994). The adjustments were made by means of nonlinear regressions, calculated by the iterative algorithm of Levenberg-Marquardt (Press et al., 1993).

\subsection{Concentrations and stocks of nitrogen and phosphorus in the biomass of S. molesta}

For the determination of the nitrogen and phosphorus concentrations, samples of plant biomass were obtained in quadruplicate in the population of macrophytes used in the beginning and end of the study in the two reservoirs. They were then washed, dried in an oven at $60{ }^{\circ} \mathrm{C}$, and milled for the determinations of total nitrogen (Allen et al., 1974) and total phosphorus (Esteves, 1980 ) as a percentage of dry mass (\% DM).

The stocks of nitrogen and phosphorus in the biomass of $S$. molesta ( $\mathrm{g} \mathrm{N}$ or P. $\mathrm{m}^{-2}$ ) were calculated by means of the Equation 2:
$\mathrm{St}=\mathrm{M} * \mathrm{C}$

where: St $=$ stock of nitrogen or phosphorus; $\mathrm{M}=$ plant mass; and $\mathrm{C}=$ concentration of nitrogen or phosphorus.

\subsection{Statistical analysis}

The variability of the temperature, $\mathrm{pH}$, electrical conductivity, turbidity, dissolved oxygen, alkalinity, transparency, total Kjeldahl nitrogen, total phosphorus, and chlorophyll- $a$ were evaluated by the Principal Components Analysis (PCA) (Bouroche and Saporta, 1982). The tests of D'Agostinho and Bartlett were applied to the values of total nitrogen and total phosphorus and the stocks of nitrogen and phosphorus in the biomass of $S$. molesta, to assess the normality and homoschedasticity of the data. Subsequently, the Analysis of Variance (oneway ANOVA) and the a posteriori Tukey test were applied (Zar, 1999). The significance level adopted was 0.05 .

\section{Results}

\subsection{Physical and chemical characteristics of the reservoir water}

The values of temperature, turbidity, electrical conductivity, alkalinity, chlorophyll- $a$, total Kjeldahl nitrogen, and total phosphorus were higher in the reservoir impacted by the discharge of effluents (IR) in all the months of the study. The maximum and minimum values of the limnological variables are shown in Table 1.

The principal components analysis summarized $72.8 \%$ of the total variability of the data from the reservoirs during the nine months of collection. Component I explained $50.42 \%$ of the total variability, whereas component II explained $22.37 \%$. Electrical conductivity, turbidity, alkalinity, total Kjeldahl nitrogen, total phosphorus, and chlorophyll- $a$ showed a positive correlation with component I, whereas transparency showed a negative correlation with the same component. Temperature showed a negative correlation with component II, and $\mathrm{pH}$ and the dissolved oxygen concentration showed a positive correlation (Table 2).

The ordination of the collection months in the two reservoirs showed a separation in component I between the two reservoirs, with monthly collections from NIR located on the left and those from IR on the right. The monthly data from the NIR showed the lower values of variables that were positively correlated with component I (conductivity, 
Table 1. Minimum (Min) and maximum (Max) values of temperature (Temp.), potential hydrogen $(\mathrm{pH})$, dissolved oxygen (DO), turbidity (Turbid.), electrical conductivity (Cond.), alkalinity (Alkal.), transparency (Transp.), chlorophyll- $a(\mathrm{Chl}-a)$, total Kjeldahl nitrogen (TKN), and total phosphorus (TP) in the non-impacted reservoir (NIR) and the effluent-impacted reservoir (IR). The months when the measurements were taken are indicated in parentheses. Hyphen (-) corresponds to the period, and comma (,) corresponds to "and".

\begin{tabular}{|c|c|c|c|c|}
\hline \multirow{2}{*}{ Variable } & \multicolumn{2}{|c|}{ NIR } & \multicolumn{2}{|c|}{ IR } \\
\hline & $\operatorname{Min}$ & Max & Min & Max \\
\hline Temp. $\left({ }^{\circ} \mathrm{C}\right)$ & 19.5 (July) & 26.5 (Jan) & 20.3 (July) & 28.6 (Jan) \\
\hline $\mathrm{pH}$ & 6.1 (Mar) & 7.8 (July) & 6.2 (Feb) & 7.4 (July) \\
\hline $\mathrm{DO}\left(\mathrm{mg} \cdot \mathrm{L}^{-1}\right)$ & 5.5 (Oct) & 8.4 (Jan) & 3.7 (Dec) & 9.2 (Aug) \\
\hline Turbid. (NTU) & 1.0 (Oct-Dec) & 5.0 (July) & 10.0 (Feb) & 60.0 (Dec) \\
\hline Cond. $\left(\mu \mathrm{S} . \mathrm{cm}^{-1}\right)$ & $19.0(\mathrm{Dec})$ & 25.0 (Jan) & 50.0 (Feb) & 82.0 (Nov) \\
\hline Alkal. (meq. $\mathrm{L}^{-1}$ ) & 0.12 (Jan) & 0.36 (Sep, Oct) & 0.43 (Jan) & 0.88 (Oct) \\
\hline Transp. (m) & 2.0 (Dec-Mar) & 2.6 (July) & 0.5 (Jul-Jan, Mar) & 1.0 (Feb) \\
\hline $\mathrm{Chl}-\mathrm{a}\left(\mathrm{mg} \cdot \mathrm{L}^{-1}\right)$ & 3.0 (July-Sep, Nov-Jan) & 16.0 (Oct) & 43.0 (Jan) & 88.0 (Oct) \\
\hline TKN (mg. $\left.L^{-1}\right)$ & $0.17(\mathrm{Nov})$ & 0.33 (Sep) & 0.27 (Feb) & 0.68 (Oct) \\
\hline $\operatorname{TP}\left(\mu g . L^{-1}\right)$ & 10.0 (July) & 33.0 (Feb) & 57.0 (July) & 167.0 (Sep) \\
\hline
\end{tabular}

Table 2. Correlations of the limnological variables of the reservoir water with components I and II of the Principal Components Analysis (PCA).

\begin{tabular}{lrr}
\hline \multirow{2}{*}{\multicolumn{1}{c}{ Variable }} & \multicolumn{2}{c}{ Principal components } \\
\cline { 2 - 3 } & \multicolumn{1}{c}{ I } & \multicolumn{1}{c}{ I } \\
\hline Temperature & 0.251 & -0.796 \\
$\mathrm{pH}$ & -0.194 & 0.852 \\
Electrical conductivity & 0.864 & 0.065 \\
Turbidity & 0.893 & 0.052 \\
Dissolved oxygen & -0.076 & 0.790 \\
Alkalinity & 0.930 & 0.079 \\
Water transparency & -0.929 & 0.115 \\
Total Kjeldahl nitrogen & 0.773 & 0.248 \\
Total phosphorus & 0.838 & -0.180 \\
Chlorophyll-a & 0.870 & 0.143 \\
\% Variation explained & 50.420 & 22.370 \\
\hline
\end{tabular}

turbidity, alkalinity, total Kjeldahl nitrogen, total phosphorus, and chlorophyll-a) and the higher value of water transparency, which is negatively correlated with the same component. Component II showed a separation by seasons of the year among the months; with the months of lower temperatures and consequently higher dissolved oxygen in the upper part of the graph (Figure 1).

\subsection{Growth and chemical composition of S. molesta}

The simple linear regression analysis between fresh and dry mass of $S$. molesta showed a correlation coefficient of 0.98 , and the equation obtained was $\mathrm{DM}=0.40457+0.01725^{*} \mathrm{FM}$, where $\mathrm{DM}=$ dry mass $(\mathrm{g})$ and $\mathrm{FM}=$ fresh mass $(\mathrm{g})$.

The growth curves of $S$. molesta in the two reservoirs are shown in Figure 2. At the beginning of the study (July/2003) the biomass was similar in both reservoirs $\left(0.7 \pm 0.1 \mathrm{~g}\right.$ DM. $\left.\mathrm{m}^{-2}\right)$. The $\mathrm{K}$ value in the NIR was $3.0 \pm 0.7 \mathrm{~g}$ DM.m ${ }^{-2}$ (Figure $2 \mathrm{a}$ ) and in the IR was $37.4 \pm 2.4 \mathrm{~g} \mathrm{DM} . \mathrm{m}^{-2}$ (Figure 2b).

The final concentrations of total nitrogen and phosphorus in the biomass of $S$. molesta in the IR were significantly higher than in the NIR. The final stocks of $\mathrm{N}$ and $\mathrm{P}$ in the biomass of $S$. molesta in the IR were also significantly higher than the stocks in the NIR (Table 3).

\section{Discussion}

The discharge of aquaculture effluents modified the limnological characteristics of the water in the impacted reservoir (IR). According to the principal components analysis, the IR had higher concentrations of total Kjeldahl nitrogen, total phosphorus, chlorophyll-a, turbidity, electrical conductivity, and alkalinity than the non-impacted reservoir (NIR). The increase in the concentrations of nitrogen and phosphorus is due to the incomplete consumption of these nutrients in the diet and fertilizers used in the aquaculture operations. In fact, a fraction of the diet consumed by the cultured organisms is eliminated through excretions and feces, and a fraction of the diet is not consumed (Arana, 2004). The results obtained in this study confirm other studies showing that aquaculture activity enriches waterbodies and causes artificial eutrophication (Baccarin and Camargo, 2005; Lin et al., 2005; Casillas-Hernández et al., 2006). Based on the total phosphorus concentrations, we established the Trophic State Index (TSI), according to Wetzel (1975), for the two reservoirs for each collection. The NIR was classified as oligomesotrophic (July and November) to eutrophic 


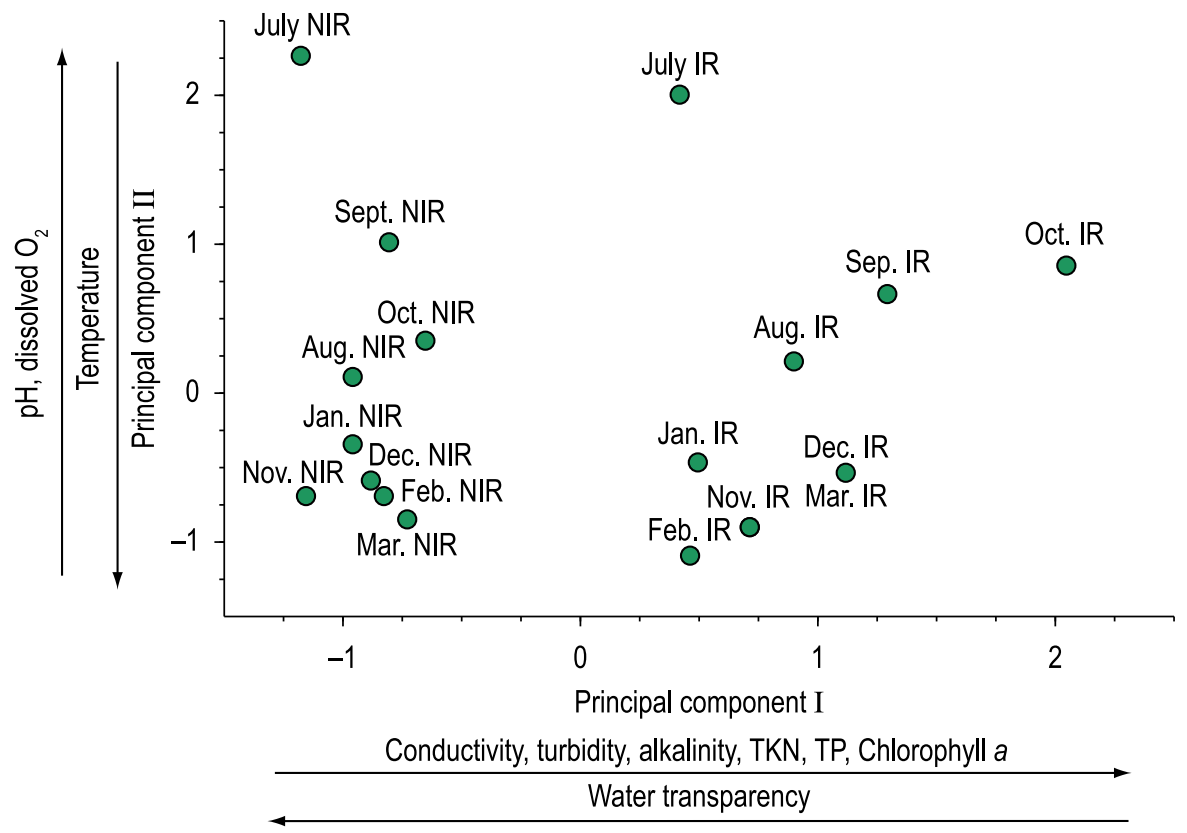

Figure 1. Ordination by Principal Components Analysis (PCA) of the collection months in the non-impacted reservoir (NIR) and the effluent-impacted reservoir (IR), based on the limnological variables analyzed. The two components explained $72.8 \%$ of the observed variation.
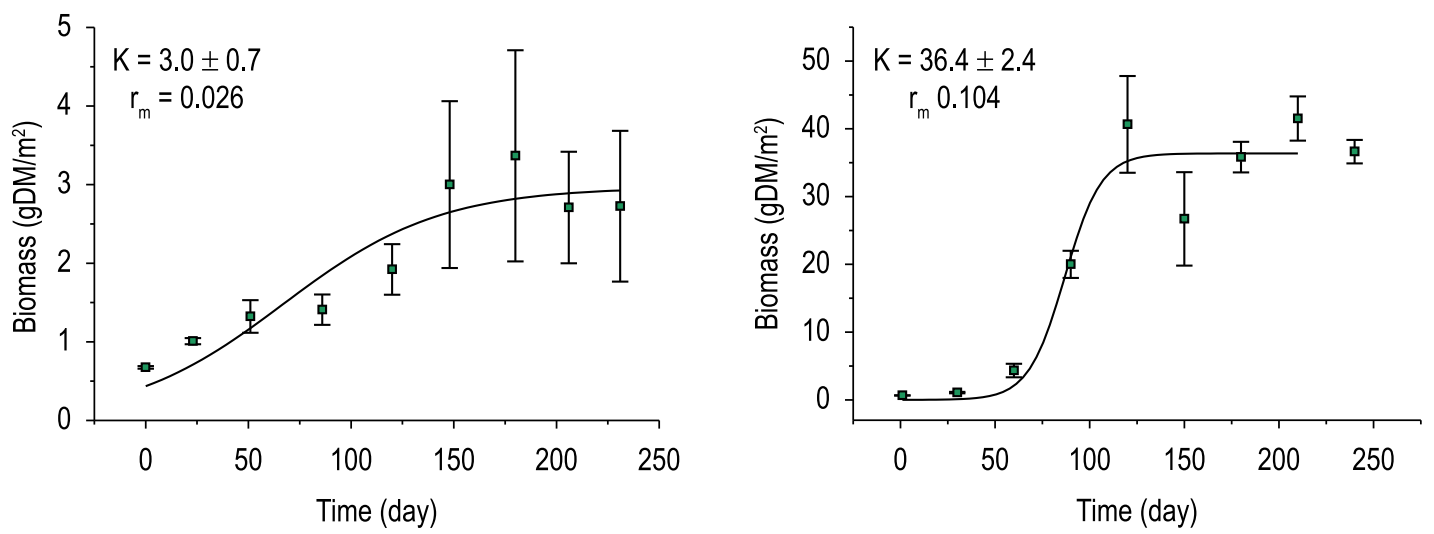

Figure 2. Growth curves of Salvinia molesta biomass (points = means; bars = standard deviations) in the non-impacted reservoir (NIR) and the effluent-impacted reservoir (IR). $\mathrm{K}$ = support capacity, $\mathrm{r}_{\mathrm{m}}=$ intrinsic growth coefficient. The graphs use different scales.

Table 3. Means and standard deviations of the concentrations and stocks of nitrogen and phosphorus in the biomass of Salvinia molesta in the non-impacted reservoir (NIR) and the effluent-impacted reservoir (IR), at the beginning and end of the study.

\begin{tabular}{lccc}
\hline \multirow{2}{*}{ Variables } & Initial & NIR & Final \\
\cline { 3 - 4 } & & $1.41 \pm 0.03^{\mathrm{a}}$ & $2.03 \pm 0.04^{\mathrm{b}}$ \\
\hline Total nitrogen (\% DM) & $1.38 \pm 0.09^{\mathrm{a}}$ & $0.20 \pm 0.01^{\mathrm{c}}$ & $0.41 \pm 0.01^{\mathrm{a}}$ \\
Total phosphorus (\% DM) & $0.22 \pm 0.01^{\mathrm{b}}$ & $29.9 \pm 22.7^{\mathrm{b}}$ & $515.9 \pm 321.8^{\mathrm{a}}$ \\
N stock (mg.m $\left.{ }^{-2}\right)$ & $9.3 \pm 0.2^{\mathrm{c}}$ & $4.2 \pm 3.2^{\mathrm{b}}$ & $104.2 \pm 65.0^{\mathrm{a}}$ \\
P stock (mg.m $\mathrm{m}^{-2}$ ) & $1.5 \pm 0.1^{\mathrm{c}}$ & & \\
\hline
\end{tabular}

Means followed by different letters indicate significant differences as assessed by Tukey's test $(\mathrm{p} \leq 0.05)$. 
(October, February and March); while the IR was classified as eutrophic in July, December, and March, and hypereutrophic in the other months.

The higher concentration of nitrogen and/or phosphorus in the IR directly influenced the growth of $S$. molesta, which reached a carrying capacity of 36.4 g DM. ${ }^{-2}$; whereas in the NIR the value was $3.0 \mathrm{~g}$ DM. $\mathrm{m}^{-2}$. These nutrients are among the main factors limiting the growth of aquatic macrophytes, because of their importance in the physiology of plants. Nitrogen is an important constituent of proteins, and phosphorus is a constituent of nucleic acids, phospholipids, nucleotides, and phosphoproteins (Larcher, 2000). Other studies have also shown a positive relationship between the growth of macrophytes and the availability of nitrogen and phosphorus. Thomaz et al. (2007), in a laboratory study, found a positive correlation between nitrogen and phosphorus in the sediment and the growth of shoots of the submersed macrophyte Egeria najas. Henry-Silva et al. (2008), in a study on wastewater treatment systems for aquaculture, observed intensive growth of the freefloating macrophytes Eichhornia crassipes, Pistia stratiotes, and Salvinia molesta. The maximum values of biomass of $S$. molesta observed in the study by Henry-Silva et al. (2008) (491 to 521 g DM.m $^{-2}$ ) were much higher than the values observed in this study, although the concentrations of total Kjeldahl nitrogen and total phosphorus in the water in the two studies were similar. The difference between the results of this study and those obtained by Henry-Silva et al. (2008) can be attributed to the smaller degree of water movement in the reservoirs of this study, in comparison to the study of HenrySilva et al. (2008) in which the macrophytes were under a constant unidirectional water flow. In fact, a moderate increase in current velocity favors the growth of aquatic macrophytes, as demonstrated by Silva (2008) for Eichhornia crassipes. The water movement reduces the thickness of the boundary layer between the environment and the plant tissues, facilitating the exchange of gases and nutrients (Westlake, 1967).

The results for composition of Salvinia molesta show that there is a relationship between the availability of nitrogen and phosphorus in the water, and the plant biomass. This relationship can possibly be explained by the importance of these two nutrients for the physiology of plants. Biudes and Camargo (2006), in a study with the emergent macrophyte Spartina alterniflora, also obtained higher concentrations of nitrogen and phosphorus in the biomass of this species, with higher concentrations of these nutrients in the environment.

One important aspect is that the production of fish in net-pens in reservoirs is a growing activity in Brazil (Zaniboni et al., 2005). According to the results of this study, the practice of aquaculture and the consequent production of residues enriched with nitrogen and phosphorus (feces, excretions, feed) can lead to undesirable growth of $S$. molesta in reservoirs, which can negatively affect the multiple uses of the aquatic ecosystem. The increase in nitrogen and phosphorus in the water also favors the growth of other floating macrophytes that are frequent in reservoirs, such as Eichhornia crassipes and Pistia stratiotes (Henry-Silva et al., 2008). In addition, the increase in nutrients in the water can alter the macrophyte community structure (Mäemets et al., 2010) and consequently that other communities that compete with, predate upon, or shelter in macrophytes.

It is concluded that the discharge of aquaculture effluents modifies the limnological characteristics of the water of the receiving aquatic environments, increasing the total Kjeldahl nitrogen, total phosphorus, and chlorophyll-a concentrations, turbidity, electrical conductivity, and alkalinity. The growth of Salvinia molesta is favored by the aquaculture effluent, probably as a result of the increase in nitrogen and phosphorus concentrations in the water.

\section{Acknowledgements}

The authors thank CNPq and FAPESP for financial support, the technician Carlos Fernando Sanches for assistance in the field and laboratory work and Dr. Janet Reid for the translation of the text.

\section{References}

AGAMI, M. and REDDY, KR. 1990. Competition for space between Eichhornia crassipes (Mart.) Solms and Pistia stratiotes $\mathrm{L}$. culture in nutrient-enriched water. Aquatic Botany, vol. 38, no. 2-3, p. 195-208.

ALLEN, SE., GRIMSHAW, HM., PARKINSON, JA. and QUARMBY, C. 1974. Chemical analysis of ecological materials. Oxford: Blackwell Scientific Publications. 565 p.

ARANA, LV. 2004. Princípios químicos da qualidade da água em aqüicultura: uma revisão para peixes $\mathrm{e}$ camaróes. 2. ed. Florianópolis: Editora da UFSC. $231 \mathrm{p}$. 
BACCARIN, AE. and CAMARGO, AFM. 2005. Characterization and evaluation of the impact of feed management on the effluents of Nile tilapia (Oreochromis niloticus) culture. Brazilian Archives of Biology and Technology, vol. 48, no. 1, p. 81-90.

BINI, LM., THOMAZ, SM., MURPHY, KJ. and CAMARGO, AFM. 1999. Aquatic macrophyte distribution in relation to water and sediment conditions in the Itaipú Reservoir, Brazil. Hydrobiologia, vol. 415, p. 147-154.

BIUDES, JFV. and CAMARGO, AFM. 2006. Changes in biomass, chemical composition and nutritive value of Spartina alterniflora due to organic pollution in the basin of the River Itanhaém (SP, Brazil). Brazilian Journal of Biology, vol. 66, no. 2, p. 781-789.

BIUDES, JFV. and CAMARGO, AFM. 2008. Estudos dos fatores limitantes à produção primária por macrófitas aquáticas no Brasil. Oecologia Brasiliensis, vol. 12 , no. 1 , p. 7-19.

BOUROCHE, JM. and SAPORTA, G. 1982. Análise de Dados. Rio de Janeiro: Editora Zahar.

BUSCHMANN, AH., CABELLO, F., YOUNG, K., CARVAJAL, J., VARELA, DA. and HENRÍQUEZ, L. 2009. Salmon aquaculture and coastal ecosystem health in Chile: Analysis of regulations, environmental impacts and bioremediation systems. Ocean \& Coastal management, vol. 52, p. 243-249.

CANARY, ACC., POERSH, L. and WASIELESKY JUNIOR, W. 2009. Impacto dos efluentes de cultivo semi-intensivo de camarão sobre a fauna bentônica no sul do Brasil. Acta Scientiarum, Biological Sciences, vol. 31, no. 4, p. 345-353.

CASILLAS-HERNÁNDEZ, R., MAGALLÓNBARAJAS, F., PORTILLO-CLARCK, G. and PÁEZ-OSUNA, F. 2006. Nutrient mass balances in semi-intensive shrimp ponds from Sonora, Mexico using two feeding strategies: Trays and mechanical dispersal. Aquaculture, vol. 258, p. 289-298.

DUARTE, CM. 1995. Submerged aquatic vegetation in relation to different nutrient regimes. Ophelia, vol. 41, p. 87-112.

ESTEVES, FA. 1980. Die bedeutung der aquatischen makrophyten für den stoffhaushalt des Schöhsees. III Die anorganischen hauptbestandteile der aquatischen makrophyten. Gewässer und Abwässer, vol. 66/67, p. 29-94.

FINDLAY, DL., PODEMSKI, CL. and KASIAN, EM. 2009. Aquaculture impacts on the algal and bacterial communities in a small boreal forest lake. Canadian Journal of Fisheries and Aquatic Sciences, vol. 66, no. 11, p. 1936-1948.

GOLTERMAN, HL., CLYNO, RS. and OHNSTAD, MAM. 1978. Methods for physical and chemical analysis of fresh waters. Oxford: Blackwell Scientific Publications. 213 p.
HENRY-SILVA, GG. and CAMARGO, AFM. 2000. Composição química de quatro espécies de macrófitas aquáticas e possibilidade de uso de suas biomassas. Naturalia, vol. 26, p. 111-125.

HENRY-SILVA, GG. and CAMARGO, AFM. 2005. Interaçóes ecológicas entre as macrófitas aquáticas flutuantes Eichhornia crassipes e Pistia stratiotes. Hoehnea, vol. 32, no. 3, p. 445-452.

HENRY-SILVA, GG. and CAMARGO, AFM. 2006. Biological treatment of Nile tilapia culture wastewaters by aquatic macrophytes. Scientia Agricola, vol. 63, p. 433-438.

HENRY-SILVA, GG., CAMARGO, AFM. and PEZZATO, MM. 2008. Growth of free-floating aquatic macrophytes in different concentrations of nutrients. Hydrobiologia, vol. 610, p. 153-160.

KREBS, CJ. 1994. Ecology: the experimental analysis of distribution and abundance package. 5 ed. New York: Pearson Addison Wesley. 816 p.

LARCHER, W. 2000. Ecofisiologia Vegetal. São Carlos: Rima. 550 p.

LIN, YF., JING, SR., LEE, DY., CHANG, YF., CHEN, YM. and SHIH, KC. 2005. Performance of a constructed wetland treating intensive shrimp aquaculture wastewater under high hydraulic loading rate. Environmental Pollution, vol. 134, no. 3, p. 411-421.

MACKERETH, FJH., HERON, J. and TALLING, JF. 1978. Water analysis: some revised methods for limnologists. Cumbria: Freshwater Biological Association. 121 p.

MÄEMETS, H., PALMIK, K., HALDNA, M., SUDNITSYNA, D. and MELNIK, M. 2010. Eutrophication and macrophyte species richness in the large shallow North-European Lake Peipsi. Aquatic Botany, vol. 92, p. 273-280.

MOOZHIYIL, M. and PALLAUF, J. 1986. Chemical composition of the water fern, Salvinia molesta, and its potential as feed source for ruminants. Economic Botany, vol. 40, no. 3, p. 375-383.

NUSCH, EA. 1980 Comparison of different methods for chlorophyll and phaeopigment determination. Archiv für Hidrobiologie, vol.14, p. 14-36.

PAÉZ-OSUNA, F. 2001. The environmental impact of shrimp aquaculture: a global perspective. Environmental Pollution, vol. 112, p. 229-231.

PRESS, WH., TEUKOLSKY, SA., VATTERLING, WT. and FLANNERY, BP. 1993. Numerical recipes in $C$ : the art of scientific computing. Cambridge: University Press. 994 p.

READ, P. and FERNANDES, T. 2003. Management of environmental impacts of marine aquaculture in Europe. Aquaculture, vol. 226, p. 139-163.

SILVA, RS. 2008. Efeito da temperatura e de cargas de nutrientes no crescimento da macrófita aquática 
Eichhornia crassipes. Universidade Estadual Paulista UNESP, Rio Claro. [Master's Thesis in Botany].

THOMAZ, SM., CHAMBERS, PA., PIERINI, AS. and PEREIRA, G. 2007. Effects of phosphorus and nitrogen amendments on the growth of Egeria najas. Aquatic Botany, vol. 86, p. 191-196.

TUNDISI, JG. and TUNDISI, TM. 2008. Limnologia. São Paulo: Oficina de textos. $631 \mathrm{p}$.

WESTLAKE, DF. 1967. Some effects of low velocity currents on the metabolism of aquatic macrophytes. Journal of Experimental Biology, vol. 75, p. 257-266.
WETZEL, RG. 1975. Limnology. Philadelphia: Saunders. $860 \mathrm{p}$.

ZANIBONI FILHO, E., NUÑER, APO., GUERESCHI, RM. and HERMES-SILVA, S. 2005. Cultivo de peixes em tanques-rede e impactos ambientais. In Seminário Cultivo de Peixes em Tanques-rede: desafios e oportunidades para um desenvolvimento sustentável. Belo Horizonte: EPAMIG. p. 57-80.

ZAR, JH. 1999. Biostatistical Analysis. 4. ed. Upper Saddle River: Prentice-Hall. 663 p.

Received: 14 June 2010 Accepted: 27 August 2010 